\title{
DINAMIKA SOSIAL EKONOMI MASYARAKAT SEKITAR HUTAN DALAM HUBUNGANNYA DENGAN MODEL PENGELOLAAN HUTAN PRODUKSI DAN SISTEM TPTII DALAM KERANGKA REDD
}

\author{
Social Economic Dynamic of Community around Forest in Correlated with Forest Product Management \\ and TPTII System with REDD \\ Gusti Hardiansyah, Rizaldi Boer, Cecep Kusmana, dan Dudung Darusman
}

\begin{abstract}
This study was conducted in the area of Intensive Silviculture/ TPTII of PT Sari Bumi Kusuma in Central Kalimantan. Research purposes to analyze the impact and build social economic activities from TPTII silvicultural systems in the scope of carbon trading. The results of the analysis showed that the increase of TPTII activities lead to the increasing recognition of indigenous people and make condusive certainty of the business. However, the employment negatively correlated to the size of planting area, the minimum life needs are still at least low compared with the poverty standard of the World Bank. Based on the results of the analysis and projections indicate that scenario increasing community development/ PMDH and implementation of a continuous TPTII can press shifting cultivation growing rate of deforestation \& degradation in the year to 50 , as compared to no guidance of other parties and TPTII activities. In term of Carbon Conservation that community love to plant attractively is rubber, meranti and tengkawang. Compensation value for carbon conservation feasible for the community of Rp. 380.000/month/family. To involve the community directly in conservation activities in the carbon framework of REDD, then suggested to the program within the community, increasing the number and skills of communities and local labor, desimination activities of TPTII to the community, and providing a compensation fund can be derived from the DR/Reforestation Fee or other source of funds.
\end{abstract}

Key words: Customary recognition, conflict, business certainty, carbon conservation, compensation

\section{PENDAHULUAN}

Masyarakat yang tinggal di sekitar kawasan hutan PT SBK yang menerapkan sistem silvilkultur intensif merupakan salah satu unsur penting untuk meningkatkan konservasi karbon dalam skala kawasan. Keberadaan masyarakat dapat mempengaruhi keberhasilan pelaksanaan konservasi karbon secara positif maupun negatif. Pengaruh positif seperti penyerapan tenaga kerja, kepastian usaha, dan meningkatnya pendapatan. Pengaruh negatif dan berpotensi menimbulkan konflik bagi perusahaan, seperti: tidak adanya pengakuan masyarakat, perambahan, keamanan tanaman dan bentuk ketidaknyamanan lainnya.

Selain konflik, aktivitas masyarakat yang semakin ekstraktif membuka areal hutan untuk memenuhi kebutuhan hidupnya melalui kegiatan perladangan berpindah, akan semakin besar pengaruhnya jika jumlah penduduk meningkat. Kondisi yang demikian dapat menyebabkan program konservasi karbon mengalami kebocoran negatif atau negative leakages dalam skala lokal dan global dari kegiatan proyek konservasi karbon.

Untuk meningkatkan potensi sosial ekonomi masyarakat dalam pengelolaan hutan secara berkelanjutan termasuk di dalamnya untuk tujuan kegiatan konservasi karbon, telah ada beberapa kegiatan yang dilakukan oleh pemerintah, swasta atau lembaga swadaya masyarakat untuk melibatkan masyarakat (community forestry atau social forestry). Salah satu kebijakan terbaru adalah adaptasi penerapan REDD (Reduced Emissions from Deforestation \& Degradation) dalam skema perdagangan karbon, dan salah satu bentuknya adalah pelaksanaan TPTII di areal PT. SBK. Permasalahan yang perlu dikaji dalam penelitian ini adalah: bagaimana dampak sistem silvikultur TPTII (Tebang Pilih Tanam Indonesia Intensif) terhadap kondisi sosial ekonomi masyarakat, dan bagaimana mengembangkan kegiatan sosial ekonomi masyarakat pada sistem silvikultur TPTII dalam lingkup perdagangan karbon. Tujuan penelitian ini adalah menganalisis dampak sosial ekonomi dan mengembangkan 
kegiatan sosial ekonomi dari sistem silvikultur TPTII dalam lingkup perdagangan karbon.

\section{BAHAN DAN METODE}

\section{Lokasi dan Waktu Penelitian}

Penelitian dilaksanakan di areal HPH PT. SBK Nanga Nuak Provinsi Kalimantan Tengah yang menerapkan Sistem Silvikultur TPTI Intensif pada bulan Maret 2007 - April 2008.

\section{Sampel Penelitian}

Sampel penelitian adalah masyarakat atau penduduk di dalam dan sekitar kawasan areal $\mathrm{HPH}$ PT Sari Bumi Kusuma. Unit analisis adalah desadesa yang berada di dalam dan sekitar kawasan dengan pendekatan purposive sampling. Sampel lokasi penelitian meliputi tiga desa sampel yaitu: Tumbang Kaburai, Sungkup dan Tanjung Paku. Pertimbangannya yaitu letak desa di dalam dan sekitar kawasan hutan, pola perladangan dan ketergantungan masyarakat terhadap hutan, dan dampak kegiatan TPTII bagi masyarakat.

Pengambilan sampel dengan metode stratified random sampling dengan responden sebanyak 47 orang dari 349 kepala keluarga pada ketiga desa tersebut. Stratifikasi responden menurut jenis pekerjaan yaitu: tokoh adat/tokoh masyarakat (5 orang), kepala desa (3 orang), petani/pekebun/peternak (20 orang), peladang/ pengumpul hasil hutan/pedagang (11 orang), pegawai lokal HPH (4 orang), Manajer Camp dan kepala bidang PMDH (2 orang), Dinas Kehutanan atau BKSDA (1 orang), dan Perguruan Tinggi (1 orang). Pertimbangan sampel relatif homogen dengan etnis dominan masyarakat Adat Dayak dan pola usaha pertanian yang hampir sama.

\section{Jenis dan Sumber Data}

Data primer diperoleh dengan metode wawancara langsung menggunakan daftar pertanyaan, meliputi: (a) persepsi mengenai pengakuan adat terhadap tanaman meranti yang ditanam, sebelum dan setelah pelaksanaan TPTII, (b) hubungan luas areal tanaman meranti dengan tingkat penyerapan tenaga kerja lokal, (c) persepsi mengenai kepastian usaha bagi pengusaha, sebelum dan setelah pelaksanaan TPTII, (d) tingkat kebutuhan hidup minimal masyarakat, dan (e) pilihan komoditas yang dinginkan oleh masyarakat jika akan terlibat dalam kegiatan mekanisme perdagangan karbon.

\section{Analisis Data}

\section{Pengakuan Adat}

Untuk mengetahui tingkat pengakuan adat dari responden, sebelum dan setelah pelaksanaan TPTII terhadap kawasan tanaman meranti di areal PT. SBK dapat dilihat pada Tabel 1. Metode analisis menggunakan Uji Wilcoxon Matched Pairs. Tahapan prosedur uji statistiknya dimulai dengan formulasi hipotesis, menentukan taraf kepercayaan, menentukan kriteria pengujian, menentukan nilai uji statistik dan membuat kesimpulan (Sugiyono, 2007 dan Hasan, 2006).

\begin{tabular}{|c|c|c|}
\hline No & Parameter Tingkat Pengakuan Adat Responden & Skala Nilai \\
\hline 1 & $\begin{array}{l}\text { Klaim terhadap tanaman meranti sebelum dan } \\
\text { setelah pelaksanaan TPTII }\end{array}$ & $\begin{array}{l}3=\text { Tidak ada klaim } \\
2 \text { = sedikit klaim (kurang dari } 1 \text { unit lahan) } \\
1 \text { = Banyak klaim (>1 unit lahan) }\end{array}$ \\
\hline 2 & $\begin{array}{l}\text { Jenis perjanjian yang disepakati antara masyarakat } \\
\text { hukum adat dengan PT. SBK terhadap tegakan } \\
\text { meranti, sebelum dan setelah pelaksanaan TPTII }\end{array}$ & $\begin{array}{l}3=\text { Ada perjanjian dan ditaati } \\
2=\text { Ada perjanjian tetapi } \text { tidak ditaati } \\
1=\text { tidak ada perjanjian }\end{array}$ \\
\hline 3 & $\begin{array}{l}\text { Keterlibatan dalam proses pembuatan perjanjian } \\
\text { hukum adat terhadap tegakan meranti, sebelum dan } \\
\text { setelah pelaksanaan TPTII }\end{array}$ & $\begin{array}{l}3=\text { terlibat langsung } \\
2=\text { kurang dilibatkan } \\
1=\text { tidak dilibatkan }\end{array}$ \\
\hline 4 & $\begin{array}{l}\text { Pengetahuan batas kawasan tegakan meranti yang } \\
\text { dikelola PT SBK, sebelum dan setelah pelaksanaan } \\
\text { TPTII }\end{array}$ & $\begin{array}{l}3=\text { Tahu } \\
2=\text { kurang tahu } \\
1=\text { tidak tahu }\end{array}$ \\
\hline 5 & $\begin{array}{l}\text { Kegiatan perladangan dalam kawasan yang dikelola } \\
\text { PT SBK, sebelum dan setelah pelaksanaan TPTII }\end{array}$ & $\begin{array}{l}3=\text { Tidak ada } \\
2=\text { Sedikit (kurang dari } 1 \text { ha) } \\
1=\text { Banyak (lebih dari } 1 \text { ha) }\end{array}$ \\
\hline 6 & $\begin{array}{l}\text { Kegiatan pengambilan atau penebangan kayu dalam } \\
\text { kawasan yang dikelola PT SBK, sebelum dan } \\
\text { setelah pelaksanaan TPTII }\end{array}$ & $\begin{array}{l}3=\text { Tidak ada } \\
2=\text { Jarang }(1 \text { kali/tahun) } \\
1=\text { Sering (lebih dari } 1 \text { kali/tahun) }\end{array}$ \\
\hline
\end{tabular}




\section{Penyerapan tenaga kerja}

Penilaian manfaat penyerapan tenaga kerja dilakukan dengan melihat hubungan antara jumlah penyerapan tenaga kerja lokal $(\mathrm{Y})$ dengan luas areal penanaman TPTI intensif (X) dalam 5 (lima) tahun terakhir yaitu periode tahun $2002-2006$. Metode analisis yang digunakan untuk menguji hipotesis yaitu menggunakan pendekatan analisis regresi.

Hipotesis yang dibangun dalam penelitian ini adalah sebagai berikut:

$\mathrm{H}_{0}$ : TPTII tidak memberikan pengaruh terhadap penyerapan tenaga kerja lokal

$\mathrm{H}_{1}$ : TPTII memberikan pengaruh terhadap penyerapan tenaga kerja lokal

\section{Kepastian usaha}

Skala penilaian dari masing-masing parameter tingkat kepastian usaha berdasarkan informasi dari responden, baik sebelum dan setelah pelaksanaan TPTII terhadap kawasan tanaman meranti di areal PT. SBK dapat dilihat pada Tabel 2.

\section{Kebutuhan Hidup Minimal Masyarakat}

Pengukuran ketercukupan hidup minimal bagi masyarakat menggunakan parameter: (a) tingkat pendapatan dan biaya hidup yang diperlukan saat ini dan yang akan datang, (b) ketersediaan lahan usahatani (ladang atau tani menetap) saat ini dan proyeksi yang akan datang, (c) jumlah penduduk saat ini dan proyeksi penduduk. Pendapatan dengan menggunakan persamaan sebagai berikut:

$$
\pi=\sum(R i j-C i j)
$$

di mana:

$\pi=$ total pendapatan masyarakat (Rp/bulan atau Rp/tahun)

$\mathrm{Rij}=$ penerimaan responden ke $\mathrm{i}$ dari setiap unit usaha j (Rp/usaha/waktu)

Cij = Biaya usaha responden ke i dari setiap unit usaha j (Rp/usaha/waktu)

$\mathrm{i}=$ responden

$\mathrm{j}=$ jenis usaha atau mata pencaharian (ladang, berburu, dagang, dan lain-lain).

\section{Kebutuhan Hidup Minimal Masyarakat}

Pengukuran ketercukupan hidup minimal bagi masyarakat menggunakan parameter: (a) tingkat pendapatan dan biaya hidup yang diperlukan saat ini dan yang akan datang, (b) ketersediaan lahan usahatani (ladang atau tani menetap) saat ini dan proyeksi yang akan datang, (c) jumlah penduduk saat ini dan proyeksi penduduk. Pendapatan dengan menggunakan persamaan sebagai berikut:

Tabel 2. Skala penilaian paramater kepastian usaha, sebelum dan setelah pelaksanaan TPTII

\begin{tabular}{|c|c|c|}
\hline No & Parameter Tingkat Kepastian Usaha Menurut Responden & Skala Nilai \\
\hline 1 & $\begin{array}{l}\text { Konflik terhadap kawasan hutan, sebelum dan setelah } \\
\text { pelaksanaan TPTII dengan tanaman meranti }\end{array}$ & $\begin{array}{l}3=\text { tidak ada konflik } \\
2=\text { sedikit konflik }(<1 \text { kali } / \text { tahun }) \\
1=\text { banyak konflik }(>1 \text { kali/tahun })\end{array}$ \\
\hline 2 & $\begin{array}{l}\text { Keamanan kawasan hutan dari perambahan (perladangan } \\
\text { dan kebakaran), sebelum dan setelah pelaksanaan TPTII }\end{array}$ & 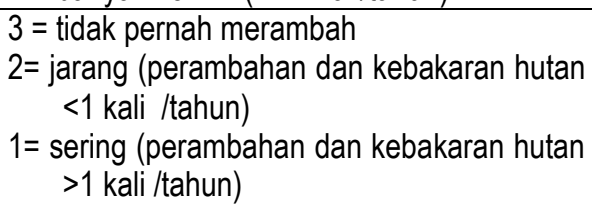 \\
\hline 3 & $\begin{array}{l}\text { Letak kawasan pemukiman atau perladangan responden } \\
\text { atau masyarakat, sebelum dan setelah pelaksanaan TPTII }\end{array}$ & $\begin{array}{l}3=\operatorname{Jauh}(>5 \mathrm{~km}) \\
2=\operatorname{sedang}(1-5 \mathrm{~km}) \\
1=\operatorname{dekat}(<1 \mathrm{~km})\end{array}$ \\
\hline 4 & $\begin{array}{l}\text { Aksesibilitas responden atau masyarakat terhadap } \\
\text { kawasan hutan yang dikelola PT SBK, sebelum dan } \\
\text { setelah pelaksanaan TPTII }\end{array}$ & $\begin{array}{l}3=\text { rendah } \\
2=\text { sedang } \\
1=\text { tinggi }\end{array}$ \\
\hline 5 & $\begin{array}{l}\text { Tanggungjawab sosial perusahaan terhadap responden } \\
\text { dan masyarakat sekitar kawasan hutan yang dikelola PT } \\
\text { SBK, sebelum dan setelah pelaksanaan TPTII }\end{array}$ & $\begin{array}{l}3=\text { tinggi } \\
2=\text { sedang } \\
1=\text { rendah atau tidak ada }\end{array}$ \\
\hline 6 & $\begin{array}{l}\text { Kebijakan pemerintah menurut persepsi repsonden yang } \\
\text { mendukung bagi pengusaha dalam pengelolaan kawasan } \\
\text { hutan, sebelum dan setelah pelaksanaan TPTII }\end{array}$ & $\begin{array}{l}3=\text { mendukung } \\
2=\text { kurang mendukung } \\
1=\text { tidak mendukung }\end{array}$ \\
\hline 7 & $\begin{array}{l}\text { Kepastian usaha masyarakat menurut persepsi repsonden, } \\
\text { sebelum dan setelah pelaksanaan TPTII }\end{array}$ & $\begin{array}{l}3=\text { tinggi } \\
2=\text { sedang } \\
1=\text { rendah }\end{array}$ \\
\hline
\end{tabular}




$$
\pi=\sum(R i j-C i j)
$$

di mana:

$\pi=$ total pendapatan masyarakat $(\mathrm{Rp} / \mathrm{bulan}$ atau Rp/tahun)

$\mathrm{Rij}=$ penerimaan responden $\mathrm{ke} \mathrm{i}$ dari setiap unit usahaj (Rp/usaha/waktu)

$\mathrm{Cij}=$ biaya usaha responden ke $\mathrm{i}$ dari setiap unit usaha j (Rp/usaha/waktu)

$\mathrm{i}=$ responden

$\mathrm{j}=$ jenis usaha atau mata pencaharian (ladang, berburu, dagang dII)

Pengukuran kebutuhan biaya hidup atas dasar pengeluaran rumah tangga menggunakan pendapatan biaya hidup selama dalam satu bulan atau satu tahun, dengan persamaan yaitu:

$$
C=\sum(C i j)
$$

di mana:

$C=$ total biaya atau pengeluaran masyarakat dalam satu bulan atau tahun (Rp/bulan atau Rp/tahun)

$\mathrm{Cij}=$ pengeluaran rumah tangga $\mathrm{ke} \mathrm{i}$ menurut jenis pengeluaran dalam satu bulan atau satu tahun (Rp/bln/KK atau Rp/thn/KK)

$\mathrm{i}$ = rumah tangga atau responden

$\mathrm{j}=$ jenis biaya rumah tangga (sandang, pangan, perumahan, pendidikan, dan kesehatan).

\section{Pendugaan Kebutuhan Lahan Masyarakat}

Pendugaan kebutuhan lahan untuk hidup minimal berdasarkan pertumbuhan jumlah penduduk didekati dengan mengadopsi persamaan laju pertumbuhan Issard (1960) dalam Simon (2004) yang dimodifikasi sesuai kebutuhan penelitian:

di mana:

$$
P_{t+0}=P_{t}(1+r)^{0}
$$

$P_{t+o}=$ jumlah penduduk dan jumlah lahan pada tahun proyeksi - ke t+o

$\mathrm{Pt}=$ jumlah penduduk dan lahan perladangan yang dimiliki saat ini- tahun dasar 2006

$r \quad=$ laju pertumbuhan penduduk dan lahan perladangan dalam 10 tahun terakhir

0 = proyeksi jumlah penduduk dan kebutuhan lahan pada 50 tahun ke depan

\section{Pemilihan Tanaman Unggulan sebagai Bentuk} Kompensasi

Analisis yang digunakan adalah analisis AHP. AHP atau Analitycal Hierarchy Process adalah salah satu metode yang telah meluas penggunaannya dalam analisis kebijakan pemerintah. Dikembangkan oleh Thomas L Saaty (1994) sebagai alat decision support system (DSS). Responden dalam penelitian ini sebagaimana dijelaskan sebelumnya.

\section{HASIL DAN PEMBAHASAN}

\section{Keragaan Masyarakat Wilayah Penelitian}

\section{Karakteristik Sosial Masyarakat}

Umur responden antara 23 - 70 tahun atau rata-rata berumur 41 tahun dan sebanyak 86,05\% adalah usia produktif (23-60 tahun). Struktur umur penduduk yang dominan dengan penduduk usia produktif akan berimplikasi pada adanya pengangguran jika tidak tersedia lapangan kerja bagi penduduk. Tingkat pendidikan masyarakat di ketiga desa sampel didominasi oleh pendidikan SD $(65,1 \%)$. Pengalaman pendidikan formal yang sebagian besar SD disebabkan oleh beberapa faktor, antara lain: biaya pendidikan yang semakin mahal, aksesibilitas ke lokasi yang lebih tinggi relatif cukup jauh, dan adanya kecenderungan dari masyarakat pedalaman hanya sekedar bisa "membaca dan menulis" akibat keterbatasan yang dimiliki oleh masyarakat setempat.

Jumlah anggota keluarga didominasi oleh 5 orang/KK $(25,5 \%)$ dengan lahan garapan sebagian besar berstatus sebagai lahan adat $(67,4 \%)$ dan sisanya sebagai lahan perorangan $(32,6 \%)$. Ratarata penguasaan lahan adalah $2,1 \mathrm{ha} / \mathrm{KK}$ dengan rata-rata lama penguasaan lahan 16,6 tahun. Dari hasil penelitian diketahui bahwa penguasaan lahan dengan status tanah adat merupakan ciri utama dari wilayah pedalaman terutama yang berdekatan dengan kawasan hutan. Namun keberadaan lahan adat dan milik belum didukung adanya sertifikat yang diakui oleh hukum negara, sehingga kadangkala posisi masyarakat lemah, khususnya menyangkut land tenure.

Jarak lahan dengan tempat tinggal rata-rata $1,3 \mathrm{~km}$. Letak lahan yang relatif cukup jauh memberikan implikasi bahwa tanah yang dapat dikelola di sekitar pemukiman penduduk semakin terbatas karena pengaruh status lahan dan juga disebabkan oleh pertambahan penduduk dengan jenis pekerjaan yang sama (perladangan berpindah), sehingga wilayah yang ada di sekitar pemukiman sudah tidak cukup menampung kegiatan usaha masyarakat. 


\section{Keragaan Ekonomi Masyarakat}

Pekerjaan masyarakat pada sampel penelitian di tiga desa didominasi petani tetap/pekebun dan peladang dan pengumpul hasil hutan sebesar $31 \%$ dan 23,8\%. Karakter masyarakat peladang/tani sawah sangat tergantung terhadap keberadaan hutan sebagai sumber lahan pertanian tradisional (berladang) yang dilakukan secara turun temurun oleh masyarakat dalam memenuhi kebutuhan dan pangan dan atau pendapatan ekonomi keluarga.

Pemanfaatan lahan untuk budidaya khususnya tanaman pertanian memberikan hasil produksi beragam. Rata-rata produksi padi adalah $1.416 \mathrm{~kg} / \mathrm{ha} / \mathrm{tahun}$. Namun hasil produksi ini masih lebih rendah jika dibandingkan dengan produksi yang seharusnya untuk tanaman padi ladang yaitu 2 ton/ha/ton. Rendahnya produksi disebabkan pemeliharaan kurang dan kondisi lahan yang digunakan sudah tidak produktif, dan atau bekas perladangan dengan masa rotasi lahan yang pendek sehingga produksi menurun dan semakin berkurang.

Pendapatan dari kegiatan berladang rata-rata Rp 1,85 juta/ha/tahun, dengan frekuensi pembukaan lahan sebanyak 1 kali/tahun. Dari hasil penelitian diketahui bahwa faktor-faktor yang mendorong terjadinya pembukaan lahan oleh responden yaitu didominasi (di atas $80 \%$ ) oleh pembukaan ladang karena merupakan lahan adat, meningkatkan income dan status lahan tidak jelas, dibanding faktor lain (kurang 80\%) kebutuhan mempunyai lahan, aksesibilitas, dan kebiasaan.

Dengan tingkat pendapatan $\mathrm{Rp} \quad 1,85$ juta/ha/thn, maka dengan asumsi satu KK memiliki luas areal 2,1 ha/KK dan jumlah anggota keluarga 5 orang akan diperoleh pendapatan perkapita perbulan sebesar Rp. 64.750/kapita/bulan. Nilai pendapatan ini lebih rendah jika dibanding dengan standar kemiskin Bank Dunia yaitu sebesar 1 US\$/kapita/hari atau setara dengan \pm Rp. 300.000/kapita/bulan.

\section{Pengakuan Adat}

Hasil Uji Wilcoxon pada Tabel 3 memperlihatkan bahwa dari enam faktor yang dapat berpengaruh terhadap adanya pengakuan adat, terdapat tiga faktor yang secara nyata memberikan pengaruh setelah pelaksanaan TPTII jika dibandingkan dengan sebelum pelaksanaan TPTII, yaitu klaim masyarakat, kejelasan batas kawasan, dan pengambilan kayu oleh masyarakat. Faktor lain seperti jenis perjanjian, keterlibatan masyarakat dan kegiatan peladangan, tidak menunjukkan perbedaan yang nyata baik sebelum maupun setelah pelaksanaan TPTII.

Dari hasil analisis menunjukan terjadi penurunan yang signifikan mengenai klaim lahan adat masyarakat, batas kawasan dan pengambilan kayu setelah pelaksanaan TPTII. Artinya bahwa pelaksanaan TPTII semakin memperjelas hak dan kewajiban antara masyarakat dan HPH. Menurut persepsi masyarakat, pada areal yang telah ditanam oleh pihak lain, tidak akan dilakukan gangguan terhadap areal tersebut, hal ini merupakan wujud saling menghargai dan mengakui aktivitas atau pekerjaan orang lain. Pengambilan kayu umumnya dilakukan pada areal yang belum dilakukan penanaman (penerapan TPTII).

Tabel 3. Uji Wilcoxon masing-masing faktor yang berpengaruh dalam menentukan besaran pengakuan adat

\begin{tabular}{|c|c|c|c|c|c|c|}
\hline & $\begin{array}{r}\text { Klaim } \\
\text { masyarakat } \\
\text { sesudah } \\
\text { TPTII - Klaim } \\
\text { masyarakat } \\
\text { sebelum } \\
\text { TPTII }\end{array}$ & $\begin{array}{r}\text { Jenis } \\
\text { Perjanjian } \\
\text { Sesudah } \\
\text { TPTII - Jenis } \\
\text { Perjanjian } \\
\text { sebelum } \\
\text { TPTII }\end{array}$ & $\begin{array}{r}\text { Keterlibatan } \\
\text { Sesudah } \\
\text { TPTII - } \\
\text { Keterlibatan } \\
\text { Sebelum } \\
\text { TPTII }\end{array}$ & $\begin{array}{r}\text { Batas } \\
\text { Kawasan } \\
\text { Sesudah } \\
\text { TPTII - Batas } \\
\text { Kawasan } \\
\text { Sebelum } \\
\text { TPTII }\end{array}$ & $\begin{array}{r}\text { Peladangan } \\
\text { Sesudah } \\
\text { TPTII - } \\
\text { Peladangan } \\
\text { sebelum } \\
\text { TPTII }\end{array}$ & \begin{tabular}{|r} 
Pengambilan \\
Kayu sesudah \\
TPTII - \\
Pengambilan \\
Kayu sebelum \\
TPTII
\end{tabular} \\
\hline$Z$ & $-2.449 \mathrm{a}$ & $.000^{\mathrm{a}}$ & $-1.890^{a}$ & $-3.000^{a}$ & $-.707^{a}$ & $-3.819 a$ \\
\hline $\begin{array}{l}\text { Asymp. Sig. } \\
\text { (2-tailed) }\end{array}$ & .014 & 1.000 & .059 & .003 & .480 & .000 \\
\hline Signifikansi & уа & Tidak & tidak & ya & Tidak & yа \\
\hline
\end{tabular}
a. Based on negative ranks.
$b$ The sum of negative ranks equals the sum of positive ranks.
c Wilcoxon Signed Ranks Test 


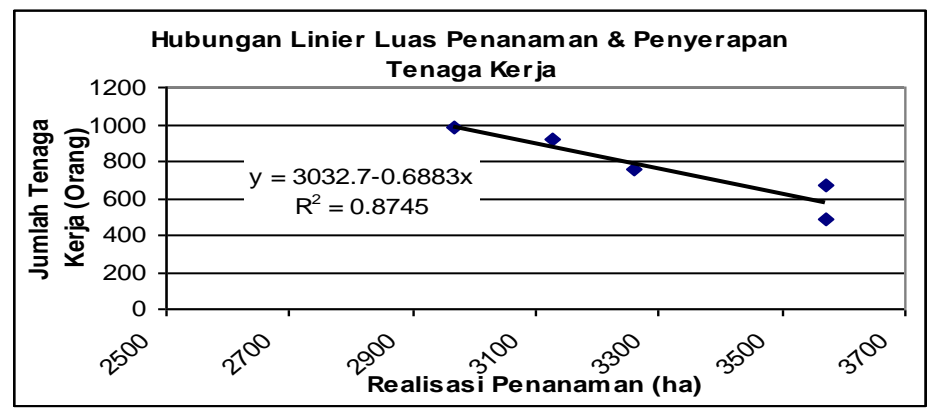

Gambar 1. Hubungan Linier Luas Penanaman dan Penyerapan Tenaga Kerja Karyawan Harian Pembinaan Hutan.

\section{Penyerapan Tenaga Kerja}

Penyerapan tenaga kerja sesudah adanya TPTII berpengaruh signifikan yaitu rata-rata meningkat 18 orang tenaga kerja/tahun, namun jumlah totalnya semakin menurun dibanding laju kenaikan areal penamaman TPTIl. Luas penanaman berkorelasi negatif dengan jumlah penyerapan tenaga kerja harian di unit Pembinaan Hutan PT SBK (Gambar 1). Hubungan negatif ini menunjukkan bahwa meskipun luas penanaman dari tahun 2002 - 2006 ada kecenderungan meningkat tetapi penyerapan tenaga kerja cenderung menurun, hal ini dipengaruhi oleh semakin efisiennya penggunaan tenaga kerja.

\section{Tingkat Pendapatan Masyarakat}

Tingkat pendapatan masyarakat menunjukkan perbedaan antara sebelum dan sesudah adanya TPTII. Hasil analisis tingkat pendapatan masyarakat meningkat secara signifikan (sangat nyata) dimana nilai sebaran $z$ sebesar - 3,771 dimana nilai $z$ ini berbasiskan rangking negatif sehingga nilai z hitung $>$ z tabel. Secara deskriptif memperlihatkan bahwa nilai rata-rata pendapatan sebesar Rp. 7.368.230,- tiap tahun atau Rp.614.019.- tiap bulan. Sementara pendapatan sebelum TPTII rata-rata sebesar Rp. 4.214.088
Itahun (Rp. 351.174/bulan). Artinya keberadaan kegiatan TPTII dapat meningkatkan pendapatan bulanan/tahunan masyarakat secara nyata. Namun masih lebih rendah dibanding Upah Minimum Regional di Provinsi Kalimantan Tengah tahun 2007 (Rp. 665.973/bulan).

\section{Kepastian Usaha}

Mengacu dari hasil analisis sosial sistem TPTII cenderung memberikan kepastian usaha bagi perusahaan, dengan indikator konflik lahan semakin berkurang, keamanan meningkat (jumlah perambah menurun), semakin sedikit lahan hutan yang menjadi ladang, tanggung jawab sosial meningkat dan kepastian usaha masyarakat semakin meningkat (Tabel 4).

Persepsi responden terhadap konflik menurun yaitu sebelum TPTII sebesar 4,76\% menjadi 2,38\% sesudah TPTII. Keamanan kawasan memperlihatkan bahwa persepsi masyarakat tidak merambah sebesar $40.5 \%$ sebelum TPTII dan menjadi $64,3 \%$ setelah TPTII atau kenaikan sebesar $23.8 \%$. Hal ini lebih menunjukkan kenaikan kesadaran masyarakat untuk tidak merambah ke hutan sehingga keamanan kawasan meningkat. Jarak pemukiman/ ladang semakin berkurang dari $46,5 \%$ sebelum

Tabel 4. Analisis Kepastian Usaha dari Kegiatan Silvikultur TPTII

\begin{tabular}{|l|l|l|l|}
\hline No & Indikator & Nilai Z & Kondisi Sosial Masyarakat Setelah Ada TPTII \\
\hline 1. & Konflik & $-2.96^{* *}$ & konflik berkurang setelah TPTII \\
\hline 2. & Keamanan & $-3.41^{* *}$ & Jumlah perambah hutan berkurang \\
\hline 3. & Letak Ladang & $-3.22^{* *}$ & Semakin menjauh dari hutan \\
\hline 4. & Aksesibilitas & $-2.95^{* *}$ & Akses ke hutan cenderung semakin sulit \\
\hline 5. & Tanggungjawab sosial & $-2.81^{* *}$ & Cenderung semakin baik \\
\hline 6. & Kebijakan Pemerintah & $0.00^{\text {tn }}$ & Tidak ada pengaruh \\
\hline 7. & Kepastian Usaha Masyarakat & $-3.37^{* *}$ & Cenderung semakin meningkat \\
\hline
\end{tabular}

Remarks: ${ }^{* *}$ sangat nyata, tn = tidak nyata 
TPTII menjadi 31,0\% setelah TPTII atau berkurang 15.5\%. Aksesibilitas masyarakat terhadap areal TPTII dan HPH sebesar $60,5 \%$ sebelum TPTII yang menurun menjadi $39.5 \%$ setelah TPTII atau menurun sebesar $21 \%$, dengan semakin jauhnya letak TPTII dari aktivitas masyarakat maka memperlihatkan bahwa pengakuan masyarakat mengalami kenaikan.

Persepsi responden terhadap konflik menurun yaitu sebelum TPTII sebesar 4,76\% menjadi 2,38\% sesudah TPTIl. Keamanan kawasan memperlihatkan bahwa persepsi masyarakat tidak merambah sebesar $40.5 \%$ sebelum TPTII dan menjadi $64,3 \%$ setelah TPTII atau kenaikan sebesar $23.8 \%$. Hal ini lebih menunjukkan kenaikan kesadaran masyarakat untuk tidak merambah ke hutan sehingga keamanan kawasan meningkat. Jarak pemukiman/ladang semakin berkurang dari 46,5\% sebelum TPTII menjadi 31,0\% setelah TPTII atau berkurang $15.5 \%$. Aksesibilitas masyarakat terhadap areal TPTII dan HPH sebesar 60,5\% sebelum TPTII yang menurun menjadi $39.5 \%$ setelah TPTII atau menurun sebesar $21 \%$, dengan semakin jauhnya letak TPTII dari aktivitas masyarakat maka memperlihatkan bahwa pengakuan masyarakat mengalami kenaikan.

Persepsi masyarkat terhadap nilai tanggungjawab sosial perusahaan cukup tinggi dan mengalami kenaikan dari $14,0 \%$ sebelum TPTII menjadi $37,2 \%$ atau naik sebesar $23.2 \%$. Kondisi ini memang sejalan dengan persepsi yang dibangun bahwa semakin besar tanggungjawab sosial maka akan semakin kecil terjadinya konflik dengan masyarakat sekitar hutan, selain itu juga perusahaan berkewajiban menjalankan CSR agar kehidupan masyarakat sekitar terbantu. Dan hal ini didukung dengan kebijakan pemerintah, dimana sebelum adanya TPTII menurut persepsi masyarakat mendukung $88,4 \%$ meningkat menjadi $93,0 \%$ atau kenaikan sebesar $4.6 \%$. Hal diatas memperlihatkan bahwa masyarakat lokal memandang bahwa pemerintah sangat mendukung adanya kegiatan TPTII sehingga secara jangka panjang diharapkan kepastian usaha semakin meningkat.

\section{Kebutuhan Hidup Minimum}

Keadaan ekonomi keluarga menggambarkan pendapatan dan pengeluaran masyarakat dalam kegiatan setiap bulan atau satuan waktu. Pendapatan masyarakat secara garis besar dibagi menjadi dua kelompok, yaitu pendapatan dari kegiatan pertanian dan pendapatan non pertanian. Adapun pengeluaran masyarakat antara lain terdiri atas pengeluaran untuk konsumsi makanan, konsumsi non makanan, transportasi.

Hasil analisis menunjukkan bahwa rata-rata pendapatan responden \pm Rp 614.019/bulan atau setara dengan $\mathrm{Rp} \mathrm{7.368.230/tahun} \mathrm{atau} \mathrm{setara}$ dengan Rp. 122.804/kapita/bulan, dengan asumsi per KK 5 orang anggota kepala keluarga. Termasuk kategori miskin jika dibanding dengan standar kemiskinan Bank Dunia (1USD/kapita/hari) atau setara Rp. 300.000/kapita/bulan. Pendekatan pendapatan tersebut diduga kurang menggambarkan kebutuhan nyata masyarakat, sehingga digunakan alternatif lain berdasarkan pendekatan pengeluaran rumah tangga. Dari pendekatan pengeluaran diketahui sebagian besar digunakan untuk biaya makan (Rp 5.155.349/tahun) dan untuk non makanan (Rp 3.960.251/tahun). Hasil analisis pengeluaran

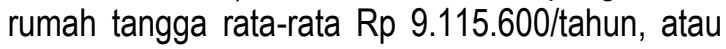
$\begin{array}{lllll}\text { perbulannya Rp. } \quad 759.633 & \text { (Rp. } 151.927\end{array}$ /kapita/bulan), masih termasuk kategori miskin. Namun, masih lebih besar jika dibandingkan pendekatan pendapatan, dengan selisih sebesar Rp. 145.614/bulan/KK. Selisih pendapatan dan pengeluaran yang tidak berimbang memberikan implikasi bahwa masyarakat belum bisa menyatakan pendapatan yang sebenarnya atau karena memang masyarakat selama ini hidup dalam kondisi yang serba kekurangan sehingga untuk memenuhi kebutuhan hidup dilakukan dengan mengutang kepada tetangga dan kemudian akan dibayar kemudian jika hasil panen berhasil.

\section{Kebutuhan Lahan Masyarakat}

Kondisi saat ini (tahun 2006) luas areal perladangan 1.501 ha dengan jumlah peladang $419 \mathrm{KK}$ atau $35 \%$ dari total kepala keluarga (1.205 $\mathrm{KK})$, luas ladang $3,6 \mathrm{ha} / \mathrm{KK}$, siklus ladang per 5 tahun, dan laju pertumbuhan penduduk $4,59 \%$. Proyeksi kebutuhan lahan perladangan dengan empat skenario yaitu: (1) kondisi saat ini, (2) ada pembinaan namun tidak ada TPTII, (3) tidak ada pembinaan dan tidak ada TPTII, (4) ada pembinaan dan TPTII ditingkatkan.

Proyeksi terhadap kondisi perladangan saat ini (Gambar 2) menunjukan luas areal perladangan akan semakin meningkat sampai pada tahun ke 50 (71.600 ha), telah melewati ambang batas ketersediaan APL (25.600 ha) pada tahun ke 28, sehingga berpotensi akan merambah ke areal lain 
seperti eks tebangan atau areal lainnya di sekitar kawasan (86.000 ha). Sedang pada skenario kedua (ada pembinaan namun tidak ada TPTII), asumsinya jumlah peladang $50 \% \mathrm{KK}$ dan faktor lain tetap menunjukkan bahwa proyeksi kebutuhan ladang sampai tahun ke 50 meningkat pesat 102.285 ha, dan telah melewati ambang batas APL (tahun ke 20) dan melewati ambang batas ketersedian areal lainnya di sekitar kawasan TPTII ( $A P L+$ eks tebangan) pada tahun ke 47. Sehingga mulai tahun ke 47 areal perladangan berpotensi masuk ke dalam areal TPTII (Gambar 3).

Pada skenario ketiga (tidak ada pembinaan dan tidak ada TPTII), diasumsikan terjadi peningkatan peladang $(75 \% \mathrm{KK})$ dan luas ladang (4 ha/KK). Hasil proyeksi kebutuhan lahan masyarakat untuk perladangan meningkat sangat pesat dibanding kondisi dua skenario sebelumnya. Pada skenario ini luas ladang tahun ke 50 (170.475 ha), ketersediaan APL dan areal lainnya hanya mampu menampung sampai tahun ke 7 dan tahun ke 34. Kondisi ini tentunya akan semakin mempercepat perambahan kawasan pada areal hutan yang dikelola dengan sistem TPTII (Gambar 4).

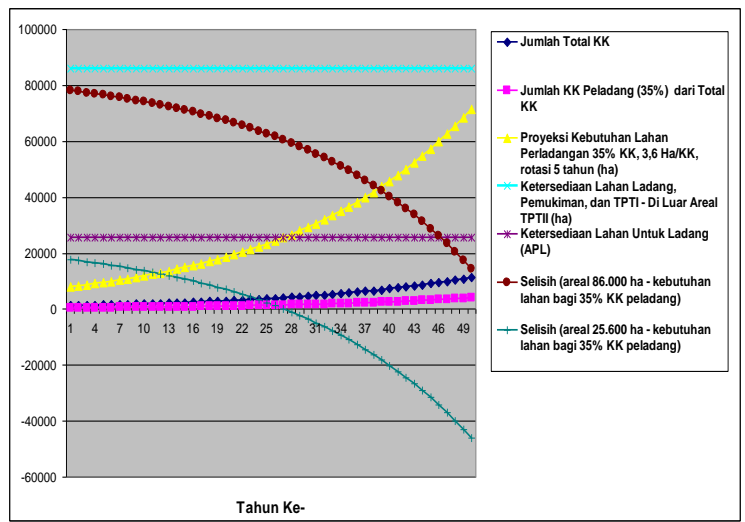

Gambar 2. Proyeksi Luas Ladang (Skenario-1)

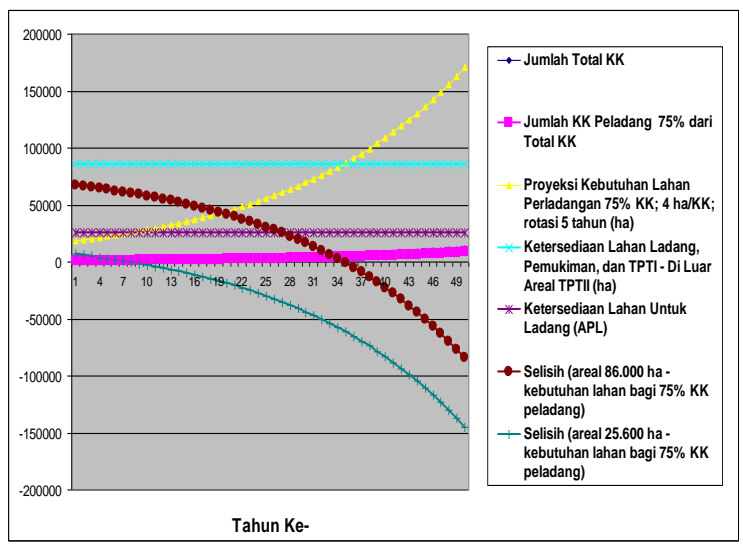

Gambar 4. Proyeksi Luas Ladang (Skenario-3)
Sedang pada skenario keempat (ada pembinaan dan TPTII ditingkatkan), diasumsikan terjadi penurunan jumlah peladang ( $20 \% \mathrm{KK})$, luas ladang $2 \mathrm{ha} / \mathrm{KK}$ dan rotasi ladang 3 tahun. Hasil analisis proyeksi kebutuhan lahan sampai tahun ke 50 pertambahan perladangan dapat ditekan dan dikendalikan yaitu seluas 13.600 ha, sehingga masih tetap di bawah ambang batas APL maupun ambang batas areal lainnya di luar areal TPTII (Gambar 5). Kondisi ini akan mendukung dalam upaya mengurangi laju deforestasi dan degradasi hutan serta akan meningkatkan keamanan kawasan TPTIl dan areal hutan lainnya dari perambahan kawasan. Oleh sebab itu, perlu adanya peningkatan skala pembinaan kepada masyarakat dan pelaksanaan TPTII yang memperhatikan kebutuhan masyarakat setempat, seperti: peningkatan alternatif mata pencaharian dan pendapatan, penyerapan tenaga kerja, bantuan pendidikan dan kesehatan, insentif pelibatan dalam kegiatan usaha kehutanan berbasis rakyat dengan mengembangkan komoditas unggulan tanaman/pohon yang bernilai ekonomi dalam kerangka konservasi karbon, dan lain-lain.

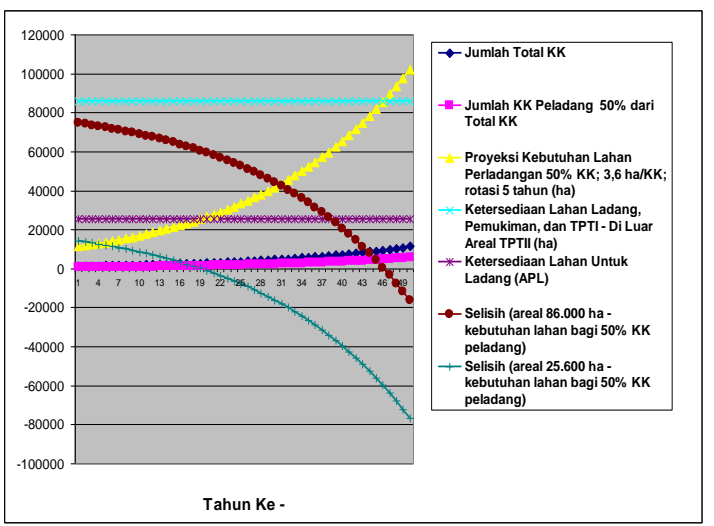

Gambar 3. Proyeksi Luas Ladang (Skenario-2)

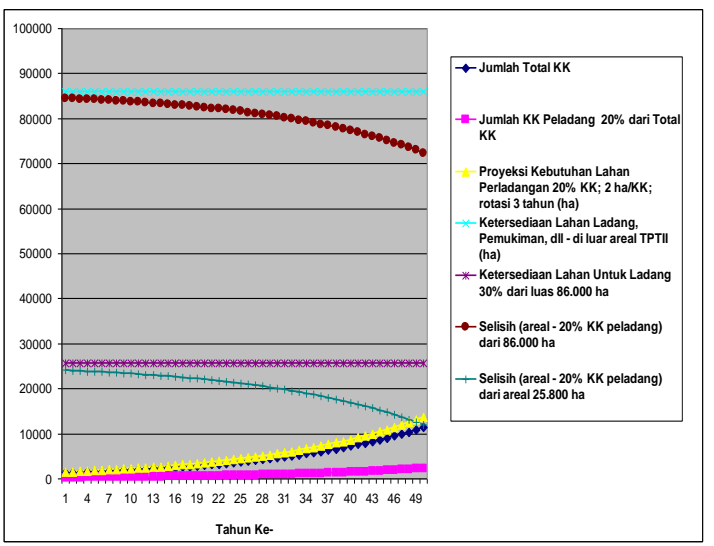

Gambar 5. Proyeksi Luas Ladang (Skenario-4) 
Pemilihan Tanaman Unggulan sebagai Bentuk Kompensasi yang Diberikan Kepada Masyarakat dalam Konteks Konservasi Karbon

\section{Pembobotan pada Tingkat Kriteria}

Hasil pembobotan AHP pada tingkat kriteria berturut-turut dari yang terbesar adalah aspek pemasaran $(25,2 \%)$, aspek penerimaan masyarakat $(24,8 \%)$, aspek budidaya $(12,0 \%)$, aspek ekonomi (11,4\%), aspek lingkungan $(10,2$ $\%)$, aspek daur $(9,1 \%)$ serta aspek penyerapan $\mathrm{CO}_{2}(7,4 \%)$.

Hasil pembobotan akhir yakni pembobotan yang telah mempertimbangkan ke-tujuh aspek tersebut di atas menempatkan jenis pohon karet sebagai prioritas utama dengan bobot $32,7 \%$, kemudian diikuti berturut-turut tengkawang (21,6 $\%)$, meranti $(17,6 \%)$, gaharu $(12,7 \%)$, sengon $(9,3$ $\%$ ) serta mahoni $(6,0 \%)$. Tingkat konsistensi pada pembobotan tingkat akhir atau alternatif ini sebesar 0,04 yang berarti perbandingan antar jenis pohon yang telah dilakukan oleh para responden konsisten karena masih di bawah 0,10.

\section{Aspek Sosial Ekonomi Lainnya dari Konservasi Karbon}

Kesediaan masyarakat terlibat dalam konservasi karbon terlihat bahwa sebagian besar masyarakat sangat setuju untuk ikut dalam konservasi karbon sebesar $93 \%$ dan tidak setuju hanya $7 \%$ walaupun masyarakat belum mengerti dengan benar apa tujuan program tersebut. Keterlibatan kelembagaan bagi masyarakat dalam pelaksanaan REDD, masyarakat menginginkan adanya lembaga yang terlibat dalam tahapan perencanaan, pelaksanaan, dan pemeliharaan dengan besaran persetujuan sebesar $76,7 \%$, $72,1 \%$, dan $69,8 \%$. Sedangkan untuk proses pemantauan, masyarakat menolaknya yaitu sebesar $55,8 \%$, dan setuju hanya $44,2 \%$.

Luas kesediaan menanam dalam rangkaian konservasi karbon oleh masyarakat rata-rata sebesar 3,1 ha, dengan kesediaan masyarakat menerima kompensasi dari konservasi karbon ratarata Rp. 607.352,-/ha/tahun atau Rp.50.612./ha/bulan. Nilai kompensasi diduga belum menggambarkan keinginan masyarakat, jika dibandingkan dengan besarnya pengeluaran dan atau pendapatan rumah tangga. Idealnya besarnya kompensasi dari berladang ke usaha-usaha konservasi lingkungan minimal sebesar Rp. 307.000/ha/bulan - Rp. 380.000/ha/bulan. Pada kondisi ini diharapkan petani akan mau mengganti lahan perladangan dan atau kebun tradisional dengan penanaman kayu pada bekas areal perladangan atau kebun masyarakat.

\section{KESIMPULAN DAN SARAN}

\section{Kesimpulan}

1. Pengakuan adat setelah pelaksanaan TPTII sangat dipengaruhi oleh klaim masyarakat, kejelasan batas kawasan, dan pengambilan kayu oleh masyarakat. Sementara jenis perjanjian, keterlibatan masyarakat, dan kegiatan peladangan tidak menunjukkan perbedaan yang nyata baik sebelum maupun setelah pelaksanaan TPTII.

2. Penyerapan tenaga kerja sesudah adanya TPTII rata-rata meningkat sebesar 18 orang tenaga kerja tiap tahun. Namun hubungan antara luas penanaman dengan penyerapan tenaga kerja berpengaruh negatif karena adanya efisiensi penggunaan tenaga kerja.

3. Faktor yang signifikan pengaruhnya terhadap kepastian usaha TPTII yaitu konflik, keamanan, letak ladang/pemukiman, aksesibilitas, tanggungjawab sosial dan kepastian usaha masyarakat.

4. Kebutuhan Hidup Minimal masyarakat atas dasar tingkat pendapatan \pm Rp 614.019/bulan (Rp 7.368.230/KK/tahun) atau setara dengan Rp. 122.804/kapita/bulan. Sedangkan pengeluaran rumah tangga sebesar $\mathrm{Rp}$ 9.115.600/tahun (Rp. 759.633/bulan/KK) atau setara dengan Rp. 151.927 /kapita/bulan. Kedua nilai tersebut masih di bawah standar kemiskinan Bank Dunia yaitu sebesar Rp. 300.000/kapita/bulan.

5. Proyeksi kebutuhan lahan perladangan masyarakat dengan menggunakan skenario peningkatan pembinaan dan pelaksanaan TPTII dari kondisi saat ini diketahui mampu menekan laju degradasi lahan / pertambahan ladang di bawah ambang batas ketersediaan APL dan areal lainnya dibanding jika tidak ada pembinaan dan tidak ada kegiatan TPTII.

6. Pemilihan tanaman unggulan sebagai kompensasi kepada masyarakat dalam konteks konservasi karbon bahwa masyarakat lebih memilih jenis tanaman Karet, Meranti, dan Tengkawang, dibanding tanaman gaharu, mahoni, dan sengon.

7. Nilai kompensasi konservasi karbon dari pendekatan pengeluaran masyarakat rata-rata Rp. Rp. 759.633 /bulan/KK dan dengan 
asumsi $50 \%$ dari pengeluaran bersumber dari pendapatan pertanian (ladang dan kebun), maka jumlah kompensasi yang paling layak untuk melibatkan masyarakat dalam kerangka konservasi karbon adalah sebesar $\mathrm{Rp}$. 380.000/bulan/KK.

\section{Saran}

1. Untuk memperkuat pengakuan adat terhadap areal TPTII maka perusahaan perlu melakukan sosialisasi yang tepat sasaran sehingga keterlibatan masyarakat dan jenis perjanjian meningkat dan kegiatan perladangan dalam areal dapat diminimalisasi.

2. Peningkatan penyerapan tenaga kerja dengan melibatkan banyak tenaga kerja lokal sehingga lebih meningkatkan taraf hidup masyarakat.

3. Kebijakan pemerintah dalam meningkatkan kepastian usaha perlu dibenahi terutama yang terkait dengan CSR maupun kegiatan produksi.

4. Mengingat pemenuhan kebutuhan hidup minimal masyarakat berbentuk "utang ke tetangga" maka disarankan untuk mendiseminasi kegiatan TPTII kepada masyarakat dengan melibatkan HPH terdekat, serta ditindaklanjuti dengan penerapan mekanisme kompensasi konservasi karbon yang sumbernya dapat berasal dari Dana DR atau pihak lain. Besarnya kompensasi minimal setara dengan pendapatan yang diperoleh masyarakat dari kegiatan perladangan.

5. Untuk menekan laju peningkatan perambahan kawasan dan kegiatan perladangan maka pemerintah dan atau pengusaha perlu meningkatkan pembinaan kepada masyarakat dan pelaksanaan TPTII melalui peningkatan alternatif matapencaharian dan pendapatan, penyerapan tenaga kerja, pengembangan hutan rakyat atau HKM dengan basis komoditas unggulan sesuai keinginan masyarakat dan konservasi karbon, bantuan usahatani menetap dan bantuan sosial ekonomi lainnya.

\section{DAFTAR PUSTAKA}

Hasan, I. 2006. Analisa Data Penelitian dengan Statistik. Cetakan Kedua. Penerbit PT. Bumi Aksara. Jakarta.

Saaty, T.L. 1994. Fundamental of decision making and priority theory with the analytical hierarchy process. RWS Publication. Pitsburg. PA.

Simon, 2004. Membangun Desa Hutan Kasus Dusun Sambiroto. Gadjah Mada University Press. Yogyakarta

Sugiyono. 2007. Statistika Untuk Penelitian. Cetakan Kesepuluh. Penerbit CV. Alfabeta. Bandung.

Diterima : 18 September 2008

\section{Gusti Hardiansyah}

Fakultas Kehutanan Universitas Tanjungpura

Pontianak, Indonesia

Rizaldi Boer, Cecep Kusmana, dan Dudung Darusman Fakultas Kehutanan Institut Pertanian Bogor

Kampus IPB Darmaga Bogor 16680 